\title{
Education, cognitive skills and earnings of males and females
}

Citation for published version (APA):

Büchner, C. I. R., Smits, W., \& van der Velden, R. K. W. (2012). Education, cognitive skills and earnings of males and females. METEOR, Maastricht University School of Business and Economics. METEOR Research Memorandum No. 010 https://doi.org/10.26481/umamet.2012010

Document status and date:

Published: 01/01/2012

DOI:

10.26481/umamet.2012010

Document Version:

Publisher's PDF, also known as Version of record

\section{Please check the document version of this publication:}

- A submitted manuscript is the version of the article upon submission and before peer-review. There can be important differences between the submitted version and the official published version of record.

People interested in the research are advised to contact the author for the final version of the publication, or visit the DOI to the publisher's website.

- The final author version and the galley proof are versions of the publication after peer review.

- The final published version features the final layout of the paper including the volume, issue and page numbers.

Link to publication

\footnotetext{
General rights rights.

- You may freely distribute the URL identifying the publication in the public portal. please follow below link for the End User Agreement:

www.umlib.nl/taverne-license

Take down policy

If you believe that this document breaches copyright please contact us at:

repository@maastrichtuniversity.nl

providing details and we will investigate your claim.
}

Copyright and moral rights for the publications made accessible in the public portal are retained by the authors and/or other copyright owners and it is a condition of accessing publications that users recognise and abide by the legal requirements associated with these

- Users may download and print one copy of any publication from the public portal for the purpose of private study or research.

- You may not further distribute the material or use it for any profit-making activity or commercial gain

If the publication is distributed under the terms of Article $25 \mathrm{fa}$ of the Dutch Copyright Act, indicated by the "Taverne" license above, 


\section{Maastricht University}

Charlotte Büchner, Wendy Smits, Rolf van der Velden

Education, cognitive skills and earnings of males and females

$\mathrm{RM} / 12 / 010$

\section{METEOR}

Maastricht University School of Business and Economics

Maastricht Research school of Economics

of Technology and Organization

PO. Box 616

NL-6200 MD Maastricht

The Netherlands 


\title{
Education, Cognitive Skills and Earnings of Males and Females
}

\author{
Charlotte Büchner, ${ }^{1 \mathrm{a}}$ Wendy Smits, ${ }^{\mathrm{b}}$ Rolf van der Velden ${ }^{\mathrm{a}}$
}

\begin{abstract}
This paper analyzes the relationship between cognitive skills, measured at age 12, and earnings of males and females at the age of 35, conditional on their attained educational level. Employing a large data set that combines a longitudinal school cohort survey with income data from Dutch national tax files, our findings show that cognitive skills and specifically math skills are rewarded on the labor market, but more for females than for males. The main factor driving this result is that cognitive skills appear to be better predictors of schooling outcomes for males than for females. Once males have achieved the higher levels of education, they more often choose programs with high earning perspectives like economics and engineering, even if their level of math skills is relatively low.
\end{abstract}

JEL Classification: I24, J16, J24, J30

Keywords: $\quad$ education, cognitive skills, gender, earnings

\section{Introduction}

Many empirical studies found evidence that cognitive skills have a positive impact on labor market outcomes of male workers (e.g. Herrnstein and Murray, 1994; Murnane, Willet \& Levy, 1995). Cognitive skills affect earnings indirectly as they determine educational attainment and directly, as more able workers may be more productive since they have better problem-solving skills and are better able to perform more complex tasks (Bound, Griliches \& Neumark, 1986; Zax and Rees, 1998; Currie and Thomas, 1999; Plug, Van Praag, and Hartog, 1999). Investments in human capital, such as in schooling and cognitive skills, are rewarded on the labor market and assumed to have similar effects for males and females (Becker, 1964). However, different specializations at school or on the job, as well as different preferences in labor market behavior (Becker, 1974) may lead to different outcomes for males and females. ${ }^{2}$ Some scholars found that males significantly differ from females in mathematical skills and in the preference for technical fields of study which indirectly

\footnotetext{
${ }^{1}$ Corresponding author: c.buchner@maastrichtuniversity.nl

${ }^{a}$ Research Centre for Education and the Labor Market (ROA), Maastricht University

${ }^{\mathrm{b}}$ Statistics Netherlands (CBS)

${ }^{2}$ Booth and Nolen (2009) assume that gender differences in behaviour are a result of social learning rather than of inherent gender traits. Parents and the social environment are likely to affect children's gender identities that eventually lead to different preferences and considerations of opportunity costs of males and females in school and at the labor market (Eagly, 1987; Chodorow, 1989; Corcoran and Courant, 1989).
} 
triggers other endowments or investments in schooling that are rewarded at the labor market (Eccles, 1986; Schmader, 2002; Brown and Corcoran, 1997; Ellison and Swanson, 2010; Niederle and Vesterlund, 2010; Pope and Sydnor, 2010). ${ }^{3}$ Studies that deal with labor market returns to cognitive skills of males and females, however, show mixed results. Cawley, Coneely, Heckman, and Vytlacil (1996) find that ability is not rewarded equally across race and gender, Heineck and Anger (2008) find that cognitive ability only affects wages of male workers. Other studies find positive, comparable effects both for males and females (Arcidiacono, 2004; Heckman, Stixrud, and Urzua, 2006). The mixed findings of these studies may result from the use of imperfect proxies for ability Results can be driven, for instance, by the design of the cognitive skills test, the age and sample selection or more or less substantial impact of personality traits and incentives taken up in cognitive skills tests. ${ }^{4}$

This study aims to analyze the earnings returns to cognitive skills for males and females in the Netherlands at age 35, conditional on their attained educational level. Using a large unique data set, we estimate cognitive skills at age 12 by three proxies, two of which are school achievement tests in math and language, and one is an IQ test to estimate more general and largely innate abilities (cf. Baltes, Staudinger, and Lindenberger, 1999). Furthermore, the analysis contains information on the field of study that was chosen at the highest educational level attained as well as controls for social background characteristics during childhood, the job sector, partner characteristics and the family composition of males and females at age $35 .^{5}$

The educational level attained and the field of study are crucial components in screening school leavers and graduates on the Dutch labor market. Individuals with higher cognitive skills are likely to attain higher levels of education. The question is whether males and females will be additionally rewarded for their cognitive skills and to the same extent on the labor market, even if they are already sorted into "appropriate" educational levels and fields of study. While Dutch males and females hardly differ anymore in years of schooling, females tend to choose other fields of study at each educational level than their male counterparts. A second question of this paper thus is to what extent the choice of field of

\footnotetext{
${ }^{3}$ Brown and Corcoran (1997), for instance, found that earnings differences can partly be explained by the fact that males and females choose different fields of study in college, even after controlling for performance. Males tend to choose more 'lucrative' fields of study that are linked to better paid occupations and industries.

${ }^{4}$ Almlund, Duckworth, Heckman, and Kautz (2011) and Borghans, Golsteyn, Heckman, and Humphries (2011) find that achievement tests take up a substantial part of personality traits and motivation and therefore predict labor market outcomes better than IQ.

${ }^{5}$ Not including contextual factors, like school and family background, would result in an overestimation of the effect of cognitive skills on earnings (Zax and Rees, 2002).
} 
study is related to cognitive skills and whether this explains differential earnings returns for males and females.

We will run earnings regressions separately by gender and use a Heckman correction to correct for unobserved heterogeneity in labor supply decisions of men and women. Furthermore, we run separate earnings regressions by educational level, since we assume that individuals, either by screening or self-selection, sort into different labor markets (Heckman et al., 2006). The specification by educational level also allows estimating how cognitive skills are related to further investments in education and to what extent returns to cognitive skills are different for males and females at each educational level.

We find significant earnings returns to cognitive skills for males and females. Math test scores thereby turn out to be a better predictor for earnings than language and IQ tests. This is also confirmed in other studies (e.g. Paglin and Ruffalo, 1990; Grogger and Eide, 1995; Murnane et al., 1995; Weinberger, 1999, 2001; Murnane, Willet, Duhaldeborde, and Tyler, 2000; Altonjii and Blank, 1999, Arcidiacono, 2004). Specifying the earning regressions by the attained educational level, the returns to math skills remain strong and significant for females at all educational levels. For males however, we only find a significant effect of math skills for the lower educated. The main factor driving this result is that cognitive skills appear to be better predictors of schooling outcomes for males than for females. Moreover, once males have achieved the higher levels, they more often choose programs with high earning perspectives like economics and engineering, even if their level of math skills is relatively low.

The remainder of the paper is structured as follows: the next section gives an overview of the data and statistical models. The results of the multivariate earning regressions, estimated separately for males and females, are reported in the third section. The last section summarizes the findings and concludes.

\section{Data and method}

Before we describe the data, it is useful to give some background information on the Dutch educational system. Figure 1 presents an overview. The arrows indicate the possible routes for proceeding from one track to the other in the educational system. The bold arrows indicate the main routes. 
The school system in the Netherlands is highly stratified from secondary education onwards. The first transition, from primary education to secondary education, takes place at the age of 12. The transition to higher education (vocational colleges and universities) takes place at around age 17 or 18 , depending on which secondary education track the student followed.

Track placement in secondary education is based on nationwide standardized skills tests, the so-called CITO tests, as well as recommendations of the class teacher at the end of primary school. Only the two highest tracks in secondary education prepare for higher education, which is the pre-college track (HAVO) for vocational colleges (HBO) and the preuniversity track (VWO) for university (WO). Both the lower general track (MAVO) and the lower vocational track (VBO) mainly prepare for upper secondary vocational education (MBO).

For the analysis we make use of a unique and rich data set, that is based on the socalled Secondary Education Pupils Cohort (SLVO) 1982 provided by Statistics Netherlands. This is a national representative longitudinal data set which contains information on some 16,800 individuals who entered secondary education in 1982 and were followed throughout their school career until they left the education system.

In the first year of the survey, when the respondents were 12 years old, skills tests were conducted in math and language as well as a test on non-verbal intelligence. At the same time information on family background was gathered by interviewing the parents of the pupils. This comprises information on ethnicity and education of the parents, family composition and attitudes toward the school career of their children.

The respondents have been followed throughout their entire educational career, with annual information about their educational status (track, grade and diploma) until they left full-time education. The data are provided by the schools, so they are of high quality.

The cohort data have been enriched with administrative data, coming from municipalities and national tax registers that provide information on labor force status and earnings of the respondents and their partners, as well as the family composition of the respondent's household (marital status, number and age of children) in 2005, at the time when the respondents were about 35 years old. The fact that these data are from registers, guarantees a high quality, especially of the earnings data. Moreover, unlike other panel studies there is no serious panel attrition which could bias our results.

We restricted the sample to males and females who were employed and who did not work in 2005 . The final data set comprises 13,337 individuals, which is about $80 \%$ of the 
original survey population. ${ }^{6}$ Earnings information is captured for about 5,800 male and 5,200 female employees. This number is large enough to allow us to run separate models for males and females. A full overview of the descriptive statistics is given in the appendix.

In the first analysis we estimate the effect of non-verbal intelligence, math and language skills on earnings separate for males and females. The earnings equation has the following form:

$Y_{i}=\beta_{0}+\beta_{1} M_{i}+\beta_{2} L_{i}+\beta_{3} I Q_{i}+\beta_{4} X_{i}+\varepsilon_{i}$

with $E\left(\eta_{i} X_{i}\right)=0$, where $\eta_{i}=\beta_{0}+\varepsilon_{i}$

where $Y_{i}$ are earnings of an individual $i . M_{i}$ denotes math skills, $L_{i}$ language skills and $I Q_{i}$ denotes non-verbal intelligence. $X_{i}$ is a vector of further observed controls and $\varepsilon_{i}$ the idiosyncratic error term.

In the second model, we allow for sorting into different labor markets, according to different levels of schooling. It is likely that cognitive skills are rewarded differently in different markets (cf. Heckman et al., 2006: 421). The returns to cognitive skills can increase with schooling, if one assumes that skills are more important at higher job levels. At the same time, the returns to cognitive skills may differ depending on whether it is regarded as a substitute for or a predictor of schooling. In the first case, we might expect stronger effects of cognitive skills (especially at lower levels of education) than in the latter case. The second equation is similar to the first one, but will allow for separate rewards (at different labor markets) for employees of different educational levels $e$ :

$$
\ln Y_{i e}=\beta_{0}+\beta_{1 e} M_{i e}+\beta_{2 e} L_{i e}+\beta_{3 e} I Q_{i e}+\beta_{4 e} X_{i e}+\varepsilon_{i e}
$$

with $E\left(\eta_{i} X_{i e}\right)=0$, where $\eta_{i}=\beta_{0}+\varepsilon_{i e}$

In all models we use a Heckman correction to control for selection of males and females into the labor market. Variables that we assume to affect females' labor supply decisions are: having a child younger than age four in the household and whether or not a possible partner has any kind of income. The selection criterion for males is whether or not he has a migration history. Using these exclusion restrictions, the inverse mills ratio is insignificant. Thus, in the

\footnotetext{
${ }^{6}$ Traag, Van der Valk, Van der Velden, and de Vries (2006) show that the group for which a match could be made with administrative data is representative for the whole sample.
} 
following, we will continue with the corrected model for male and female labor market selection. The following section presents and discusses the findings of the descriptive and multivariate analyses.

\section{Results}

Table A.1 in the appendix shows some descriptive statistics. Starting with our dependent variable, we can note the familiar gender differences in earnings. In 2005, females' average $\log$ earnings were $20 \%$ lower than those of males, and this holds for each attained level of education (see Table A.2 in the appendix). As to the labor force status, differences between males and females are also statistically significant. In $2005,81 \%$ of the males were in fulltime employment, $11 \%$ were in part-time employment while $9 \%$ had no job (unemployed or out of the labor force). For females these figures were 23\% (full-time employed), 54\% (parttime employed), and 23\% (no job).

With respect to the cognitive skills, we can note that males have on average higher math scores at age 12 than girls, while girls score higher in language and non-verbal intelligence tests. The difference in math scores is around 1/5 of a standard deviation. Although some studies found that the gender gap in achievement tests has narrowed over time (Hyde, Fennema, and Lamon, 1990; Ellison and Swanson, 2010; Niederle and Vesterlund, 2010; Pope and Sydnor, 2010), our results show that differences in math, language and non-verbal intelligence tests between girls and boys are statistically significant for this cohort and this holds for each educational level. As math and language tests in the Netherlands at age 12 are used to sort students into different school tracks, test scores also significantly differ between males of different educational levels and females of different educational levels (see Table A.2 in the appendix).

There is hardly any gender difference in years of schooling (12.5 years for males and 12.6 years for females), but there are significant differences in the choice of field of study. Males dominate in engineering studies, while females represent the majority in health studies at all education levels (Table A.2 in appendix). On average, more than a third of the males chose engineering, while only $6 \%$ of the females did so. In health studies one third of the females can be found, while only $2 \%$ of the males chose this field. Economics studies is equally chosen by males and females at the intermediate education level, while significantly more females than males chose this field of study at the lower education level and significantly more males than females at the higher education level. 
Tables $1 \mathrm{a}$ and $1 \mathrm{~b}$ present the results of the earnings regressions separately for all males and females. The first two columns present the model for the total group (eq. 1) and the other columns the results per level of education (eq. 2). The first column in the model for the total group shows the effect of cognitive skills without controls for schooling and background characteristics. Without controlling for other characteristics, cognitive skills explain some 7\% of the earnings of males and $9 \%$ of the earnings of females, with the strongest effects for math and languages skills. ${ }^{7}$

After controlling for schooling and field of study in the second model for the total group, the effects of cognitive skills decrease but the math skills still have an effect on earnings, both for males and females. An increase in math skills of one standard deviation is associated with a wage premium of $2.9 \%$ for males and $3.7 \%$ for females. ${ }^{8}$ While higher scores in language skills and non-verbal intelligence do not play a significant role for males' earnings anymore after controlling for schooling, females still profit from it. An increase in females' language skills and non-verbal intelligence of one standard deviation is related to a wage premium of $2.6 \%$ and $1.2 \%$, respectively.

Including further controls for social background and the current family composition of the respondent in the third model of all males and females do not substantively change the values of the cognitive skills coefficients. ${ }^{9}$

The results show that the achievement tests have a greater predictive power than the IQ test in explaining earnings differentials. Almlund et al. (2011) and Borghans et al. (2011) explain this by the fact that achievement tests take up a substantial portion of personality indicators that play an important role in predicting life outcomes.

\footnotetext{
${ }^{7}$ The bivariate correlations between math scores and earnings are 0.29 for males and 0.27 for females. For languages scores these correlations are 0.24 and 0.25 respectively and for IQ scores the corresponding figures are 0.12 and 0.15. This is comparable to the estimates found in studies of Cameron and Heckman (1993) and Heckman et al. (2006), but they are smaller than the estimates in Neal and Johnson (1996) and Zax and Rees (2002).

${ }^{8}$ Note that this wage effect of math skills is related to schooling. As schooling is a choice variable and depends on cognitive skills, schooling is endogenous in the earnings equation (Heckman et al., 2006). Therefore the returns to math skills are lower than in a model without schooling.

${ }^{9}$ For some control variables there is a higher number of missing values in the final sample, but they are not related systematically to cognitive skills or other (demographic) characteristics of the respondent. These variables are father's and mother's schooling, parental educational support at age 12, whether or not having a higher educated partner and partner's age. In order to avoid too many drop outs in the earnings regressions, we replaced the missing information by the population mean and included a dummy in the regressions indicating the missing value. This has no effect on the other coefficients and yields similar results as running the models without this procedure.
} 
As indicated earlier, the first earnings equation assumes that returns to cognitive skills are the same for each level of schooling. That is a strong assumption. Schooling is crucial to improve an individual's labor market outcome and usually sorts people into different labor markets and occupations. We may also expect that skills are differently rewarded in these labor markets, with some skills being specifically rewarded in high level jobs. At the same time, cognitive skills can serve as a substitute for schooling, thus leading to higher returns for the lower educated. Interestingly, the results for the second equation, which specifies the model by level of education, shows that in the case of males this effect of math skill on earnings is only significant for lower educated males, while for females the effect of math skills remains significant for all levels of education and is even highest for the higher educated females ( $4 \%$ wage premium for a one standard deviation increase in the math skills, compared to only $1.3 \%$ for males).

For lower educated females we also note significant earnings effects of language skills which are absent in the case of males of all specifications. ${ }^{10}$ For those women the wage premium of language skills is even higher than of math skills.

Tables $1 \mathrm{a}$ and $1 \mathrm{~b}$ also show how earnings are affected by the choice of field of study. For lower and medium educated males and females the differences by field of study are rather small, but for higher educated the field of study is an important determinant of earnings. Economics ${ }^{11}$ is by far the most lucrative field of study in higher education. For males the earnings advantage is $10 \%$ compared to engineering, $15 \%$ compared to agriculture and health and 25\% compared to other studies (social studies, humanities and arts). For females the wage premium of having followed a study in economics in higher education is about $9 \%$ compared to engineering, about $13 \%$ compared to health and about $18 \%$ compared to 'other studies'.

\section{<Figures $2 a, b$ and c about here >}

\footnotetext{
${ }^{10}$ The effect of math skills on males' and females' log earnings does not explain much of the gender wage gap. As indicated in Table A1 of the appendix, males' average earnings are $20 \%$ higher than those of females. Including math skills reduces males' earnings advantage by some $2 \%$, while controlling for language skills or non-verbal intelligence slightly increases the effects for males on earnings (analyses are available on request).

${ }^{11}$ This is the reference category and includes also business studies.
} 
Figures 2a-2c show the effect of cognitive skills on earnings graphically. This model includes a quadratic effect of cognitive skills on earnings to allow for non-linearity. ${ }^{12} \mathrm{We}$ can draw some interesting conclusions from this. All three figures show the familiar pattern of higher earnings for males than for females. Figure $2 \mathrm{a}$ shows that for females the returns to math skills is almost linear, but for males the returns to low math skills are relatively high. We will return to that issue below. Figure $2 b$ shows that the returns to language skills is linear for both males and females, but the effect is stronger for females (albeit not as strong as for math skills). Figure $2 \mathrm{c}$ shows a small linear effect of IQ on earnings for females, and weak effect for males that clearly tapers off at the high end of the scale.

How can these gender differences in the returns to cognitive skills be explained? All these estimates are controlled for selection effects of female's labor supply decisions and for field of study. This implies that the results are not driven by gender differences in the sorting process in education or at the labor market. We also performed additional analyses with controls for job sector and part time work, ${ }^{13}$ but this does not change the substantive results. We therefore conclude that the results do no stem from ending up in different kinds of jobs.

There is no a priori reason to think that employers value math skills in similar jobs differently for males and females. Apparently there must be another reason why we find these effects for females and not for males and we assume that this is related to a differential sorting process in school.

\section{$<$ Table 2 about here>}

Table 2 reports the results of the regression of years of schooling on the cognitive skills of males and females at age 12. We can see that the three skills measures 'explain' years of schooling of males better than they do for females: $24 \%$ versus $18 \%$. The only skill measure that is a stronger predictor of years of schooling for females than for males is the IQ score, but this is also the weakest predictor of all three. Both math skills and language skills predict years of schooling better for males than for females and the difference is significant.

\footnotetext{
${ }^{12}$ In these models we control only for cognitive skills and their quadratic effect. Full results of the analyses are available on request.

${ }^{13}$ We additionally run models which include unemployed respondents, with controls for job sector as well as models with interaction terms for math skills and a part time-dummy, and for math skills and a public sectordummy, assuming that working part-time or in a public sector is negatively associated with math skills. The results from Tables $1 \mathrm{a}$ and $1 \mathrm{~b}$ on the returns to cognitive skills are robust to these tests. The estimates of the two interaction terms are not significant nor did they change the magnitude of the math skills-coefficient considerably.
} 
The results also hold if we control for background characteristics like schooling of the parents, migration history or number siblings.

\section{$<$ Figures $3 a$ and $3 b$ about here $>$}

Figures $3 \mathrm{a}$ and $3 \mathrm{~b}$ confirm this in graphical form. They show the probability of males and females having a higher education degree at the different levels of the cognitive skills measures. The slopes for math and language scores of males show a steeper increase in the probability of graduating from a vocational college or university than those of females.

\section{$<$ Table 3 about here $>$}

Table 3 reports the predicted marginal effects of graduating from a particular field of study. This table only shows the results for the field of study in higher education. The full results for the other levels of education are available in the appendix (Table A3a and A3b).

Males with high math scores more often choose engineering and less often 'other studies' (i.e. social studies, humanities and arts), while the reverse is true for high language skills. For females this pattern is slightly different. Like males, females with high math scores are more likely to choose engineering, but at the expense of health studies, while females with high language scores more often graduate from an economics program and less often from engineering.

\section{$<$ Figures $4 a$ and $4 b$ about here $>$}

Figures $4 \mathrm{a}$ and $4 \mathrm{~b}$ show the predicted probabilities of graduating from an engineering program or an economics program. For engineering we see that the probability of graduating from such a program is much higher if one has higher math skills and this holds even stronger for males than for females. For economics we see something different. Males with low math skills have considerably higher chances to graduate from such a program than females with low math skills. The probability of graduating from an economics program for both gender groups converges only for the highest math levels. In other words, males with relatively low math skills still choose a lucrative field like economics with high returns, while females only choose such a study when they have high math skills. 
To summarize, cognitive skills and specifically math skills are rewarded on the labor market, but more for females than for males. The main factor driving this result is that cognitive skills appear to be better predictors of schooling outcomes for males than for females. Moreover, once males have achieved the higher levels, they more often choose programs with high earning perspectives like economics and engineering, even if their level of math skills is relatively low.

\section{Conclusion}

Recent studies on returns to cognitive skills vary in their results regarding labor market outcomes of males and females. This paper analyses earnings returns to cognitive skills using a unique data set consisting of longitudinal data of the Secondary Education Pupils Cohort (SLVO), combined with earnings information from national tax files from Statistics Netherlands. We apply different measures of cognitive skills obtained at the age of 12 , and control for social background, field of study, job and partner characteristics and the family situation at the time when earnings are observed. We correct for sample selection bias, regarding male and female labor supply decisions.

Our findings show that both males and females get a wage return to having higher math skills. Females profit to a lesser extent also from having higher language skills and a higher IQ. A further specification of the earning regressions by educational level indicates that math skills only affect the earnings of lower educated males, while for females the effects are significant for all levels, but strongest for the higher educated.

These differences in the earnings returns to cognitive skills cannot be explained by differential sorting on the labor market. In the analyses we control for the sample selection bias of women's labor supply decisions and we also control for field of study, as well as for job sector and part time work (in additional robustness analyses), so the results do not stem from ending up in different kinds of jobs.

We argue that the process through which cognitive skills are converted into schooling outcomes (both years of schooling and field of study) is different for males and females. For males the effect of cognitive skills is largely indirect, affecting their level of schooling and their field of study. For females on the other hand, we can note that the cognitive skills do no fully convert into years of schooling or field of study. The predictive effect of cognitive skills on years of schooling for females is $18 \%$ compared to $24 \%$ for males. Nevertheless, the gender differences on the cognitive tests and on years of schooling are relatively minor. This 
means that part of the success of females in achieving higher levels of schooling must be attributed to other factors, such as motivation or diligence. The literature on the educational success of women indeed points to such characteristics that help explain the effect (Francis, 2006; Buchmann, DiPrete, and McDaniel, 2008). Our results however suggest that the success of females in education could even be stronger if selection would have been based more on their cognitive skills as in the case of males. We also saw that in higher education males with low math scores have a relatively high chance of choosing a program in economics (with the highest expected earnings), while females with low math skills are less prone taking such a program.

From our results we presume that the meritocratic process in education works better for males than for females. Males are selected more than females to higher levels of education on the basis of their cognitive skills, and once they have achieved the higher levels, they more often choose programs with high earning perspectives like economics and engineering, even if their level of math skills is relatively low.

We conclude that in the case of females, there is still a reserve of talent that is not fully 'recognized' in the education system, but that is nevertheless rewarded on the labor market.

\section{References}

Almlund, M., Duckworth, A.L., Heckman, J.J. \& Kautz, T. (2011). Personality Psychology and Economics. IZA Discussion Paper, No. 5500.

Altonjii, J.G., \& Blank, R. (1999). Race and Gender in the Labor Market. In: Ashenfelter, O., and D. Card (ed.), Handbook of Labor Economics, 3c: 3144-3259. Amsterdam: Elsevier Science.

Arcidiacono, P. (2004). Ability Sorting and the Returns to College Major. Journal of Econometrics, 121, 343-375.

Baltes, P.B., Staudinger, U.M., \& Lindenberger, U. (1999). Lifespan psychology: Theory and application to intellectual functioning. Annual Review of Psychology, 50, 471-507.

Becker, G. (1964). Human Capital: A Theoretical and Empirical Analysis, with Special Reference to Education. Chicago, University of Chicago Press

Becker, G. (1974). A theory of marriage, part II. Journal of Political Economy, 82, 11-26.

Booth, A. L., \& Nolen, P. (2009). Gender Differences in Risk Behaviour: Does Nurture Matter?, Disscussion Paper of the Centre for economic Policy Research, No. 7198. 
Borghans, L., Golsteyn, B., Heckman, J., \& Humphries, J. (2011): Identification Problems in Personality Psychology, IZA Discussion Paper, No. 5605.

Bosker, R., Hofman, A., \& van der Velden, R. (1985). Een generatie geselecteerd. Deel 1: De loopbanen. Interimrapport van het SVO-project 1042. Groningen: RION.

Bosman, M.H. (1993). Opvoeden in je eentje: een onderzoek naar de betekenis van het moedergezin voor de onderwijskansen van kinderen, Dissertation, University of Groningen: http://dissertations.ub.rug.nl/faculties/ppsw/1993/m.h.bosman/

Bound, J., Griliches, Z., \& Neumark, B. (1986). Wages, schooling and IQ of brothers and sisters: Do the family factors differ? International Economic Review, 27, 77-105.

Brown, C. \& Corcoran, M. (1997). Sex-Based Differences in School Content and the MaleFemale Wage Gap. Journal of Labor Economics, 15 (3), 431-465.

Buchmann, C., DiPrete, T., \& McDaniel, A. (2008). Gender inequalities in education. Annual Review of Sociology, 34, 319-337.

Cameron, S.V., \& Heckman, J.J. (1993). The Nonequivalence of High School Equivalents. Journal of Labor Economics, 11, 1-47.

Cawley, J., Coneely, K., Heckman, J., \& Vytlacil, E. (1996). Measuring the Effects of Cognitive Ability. NBER Working Paper 5645.

Centraal Bureau voor de Statistiek (1987). Standaardonderwijsindeling 1978. Den Haag.

Chodorow, N. (1989). Feminism and Psychoanalytic Theory. New Haven, CT: Yale University Press.

Corcoran, M., \& Courant, P. (1989). Sex-Role Socialization, Screening by Sex, and Occupational Segregation. Working Paper. Ann Arbor: University of Michigan.

Currie, J., \& Thomas, D. (1999). Early test scores, socioeconomic status and future outcomes. NBER Working Paper, 6943. Cambridge, Massachusetts.

Eagly, A.H. (1987). Sex Differences in Social Behavior: A Social Role Interpretation. Hillsdale, NJ: Erlbaum.

Eccles, J. (1986). Gender-Roles and Women's Achievement. Educational Researcher, 15(6), 15-19.

Ellison, G., \& Swanson, A. (2010). The Gender Gap in Secondary School Mathematics at High Achievement Levels: Evidence from the American Mathematics Competition. Journal of Economic Perspectives, 24(2), 109-128.

Francis, B. (2006). Heroes or zeroes? The discursive position of 'underachieving boys' in English neo-liberal education policy. Journal of Education Policy, 21, (2), 187-200. 
Grogger, J., \& Eide, E. (1995). Changes in College Skills and the Rise in the College Wage Premium. Journal of Human Resources, 30(2), 280-310.

Heckman, J.J., Stixrud, J., \& Urzua, S. (2006). The Effects of Cognitive and Noncognitive Abilities on Labor Market Outcomes and Social Behavior. Journal of Labor Economics, 24(3), 411-482.

Heineck, G., \& Anger, S. (2008). The Returns to Cognitive Abilities and Personality Traits in Germany, Discussion Papers, 836, DIW, Berlin.

Herrnstein, R.J. \& Murray, C. (1994). The Bell Curve: Intelligence and Class Structure in American Life. New York: The Free Press.

Horn, W. (1969). Prüfsystem für Schul- und Bildungsberatung PSB. Göttingen: Verlag für Psychologie.

Hyde, J.S., Fennema, E., \& Lamon, S.J. (1990). Gender Differences in Mathematic Performance: A Meta-Analysis. Psychological Bulletin, 107(2), 139-55.

Murnane, R.J., Willet, J.B., \& Levy, F. (1995). The Growing Importance of Cognitive Skills in Wage Determination. The Review of Economics and Statistics, 77(2), 251-266.

Murnane, R.J., Willet, J.B., Duhaldeborde, Y., \& Tyler, J.H. (2000). How Important Are the Cognitive Skills of Teenagers in Predicting Subsequent Earnings? Journal of Policy Analysis and Management, 19(4), 547-68.

Neal, D.A., \& Johnson, W.R. (1996). The Role of Premarket Factors in Black-White Wage Diffrences. Journal of Political Economy, 104, 869-895.

Niederle, M., \& Vesterlund, L. (2010). Explaining the Gender Gap in Math Test Scores: The Role of Competition. Journal of Economic Perspectives, 24(2), 129-144.

Paglin, M., \& Ruffalo, A.M. (1990). Heterogeneous Human Capital, Occupational Choice, and Male-Female Earnings Differences. Journal of Labor Economics, 8(1, Part 1), 123-44.

Plug, E., Van Praag, B., \& Hartog, J. (1999). If We Knew Ability, How Would We Tax Individuals? Journal of Public Economics, 72, 183-211.

Pope, D.G., \& Sydnor, J.R. (2010). Geographic Variation in the Gender Differences in Test Scores. Journal of Economic Perspectives, 24 (2), 95-108.

Schmader, T. (2002). Gender Identification Moderates Stereotype Threat Effects on Women's Math Performance. Journal of Experimental Social Psychology, 38, 194201.

Traag, T., van der Valk, J., van der Velden, R., \& de Vries, R. (2006). Dertigers op de arbeidsmarkt, ROA-R-2006/2. 
Weinberger, C.J. (1999). Mathematical College Majors and the Gender Gap in Wages. Industrial Relations, 38, 407-13.

Weinberger, C.J. (2001). Is Teaching More Girls More Math the Key to Higher Wages? Chap. 11, in: M. C. King (ed.), Squaring Up: Policy Strategies to Raise Women's Incomes in the United States. University of Michigan Press.

Zax, J., \& Rees, D. (1998). Environment, Ability, Effort and Earnings. Denver, Center for Research and Social Policy, Working Paper 9801.

Zax, J., \& Rees, D. (2002). IQ, Academic Performance, Environment, and Earnings. The Review of Economics and Statistics, 84(4), 600-616. 


\section{Appendix: Description of variables and summary statistics}

We used three measures for cognitive skills, all measured at age 12. The math and language tests are based on the so-called CITO test, a nationwide standardized school performance test (comparable to the SAT). Each test comprises 20 multiple choice questions. The sum-score is standardized with mean zero and standard deviation one. Cronbach's alpha for the math test is 0.80 and 0.70 for the language test (Bosman, 1993). Furthermore, a non-verbal intelligence test was done on logical reasoning and the capacity to abstract (Horn, 1969). The test comprises 40 items of which the sum-score again is standardized with mean zero and standard deviation one. Cronbach's alpha for this test is 0.79 (Bosman, 1993).

Schooling refers to the highest educational level attained and is measured in years, on a scale ranging from 6 to 19 years, according to the 'years of schooling ladder' by Bosker, Hofman and Van der Velden (1985), which measures the progress to the top of the Dutch educational system (19 years for completing university). Field of study refers to the field of study observed at the highest educational level attained: we use six dummy-variables assigned to agriculture, economics, engineering, health, general and other.

Information on family background is given by the parents of the pupils at the start of the panel survey at age 12:

Having a migration history is measured by the country of birth of both the respondent and one of his or her parents. Someone is considered to belong to an ethnic minority if either the respondent or his or her parents were born in one of the non-western countries listed in the Employment of Minorities (Promotion) Act (Wet SAMEN).

Siblings is a dummy indicating whether the respondents has siblings (1) or not (0).

The educational level of the parents was determined according to the Standard Education Classification 1978 (Centraal Bureau voor de Statistiek, 1987). The different levels were then converted to the average number of years of education according to the above-mentioned scale by Bosker et al. (1985). The following values were assigned: 6 years (primary education, ISCED 0-1), 10 years (secondary education, lower level, ISCED 2), 14 years (secondary education, higher level, ISCED 3), 17 years (tertiary education, first phase, ISCED 5 bachelor) and 19 years (tertiary education, second phase, ISCED 5 master or ISCED 6).

The amount of parental educational support was based on questions to both parents about having discussions about school, having discussions about school performance and giving 
compliments about school performance. These items were combined to provide a scale with a minimum value of 0 and a maximum value of 1 . The Cronbach's alpha is 0.61 .

The panel data have been matched with administrative data, coming from municipalities and national tax registers that provide information on labor force status and earnings of the respondents and their partners, as well as the family composition of the household in 2005, at the time when the respondents were about 35 years old.

From the register of the municipalities we obtain whether the respondent at that time was living with a partner (dummy), the age of a partner, the number and age of children in the household.

The labor force status of the respondent is measured as being in full-time, part-time or having no job in September 2005.

The earnings information of the respondent is based on the logarithm of average gross monthly earnings in September 2005. The earnings are standardized by means of a part-time factor, ranging from 0.1 to 1 full-time equivalent.

Having a higher educated partner comes from register data. The dummy takes value 1 , if the partner has attained a degree at a vocational college (HBO) or at university (WO), and takes value 0 otherwise. 


\section{Figure 1. The Dutch educational system}

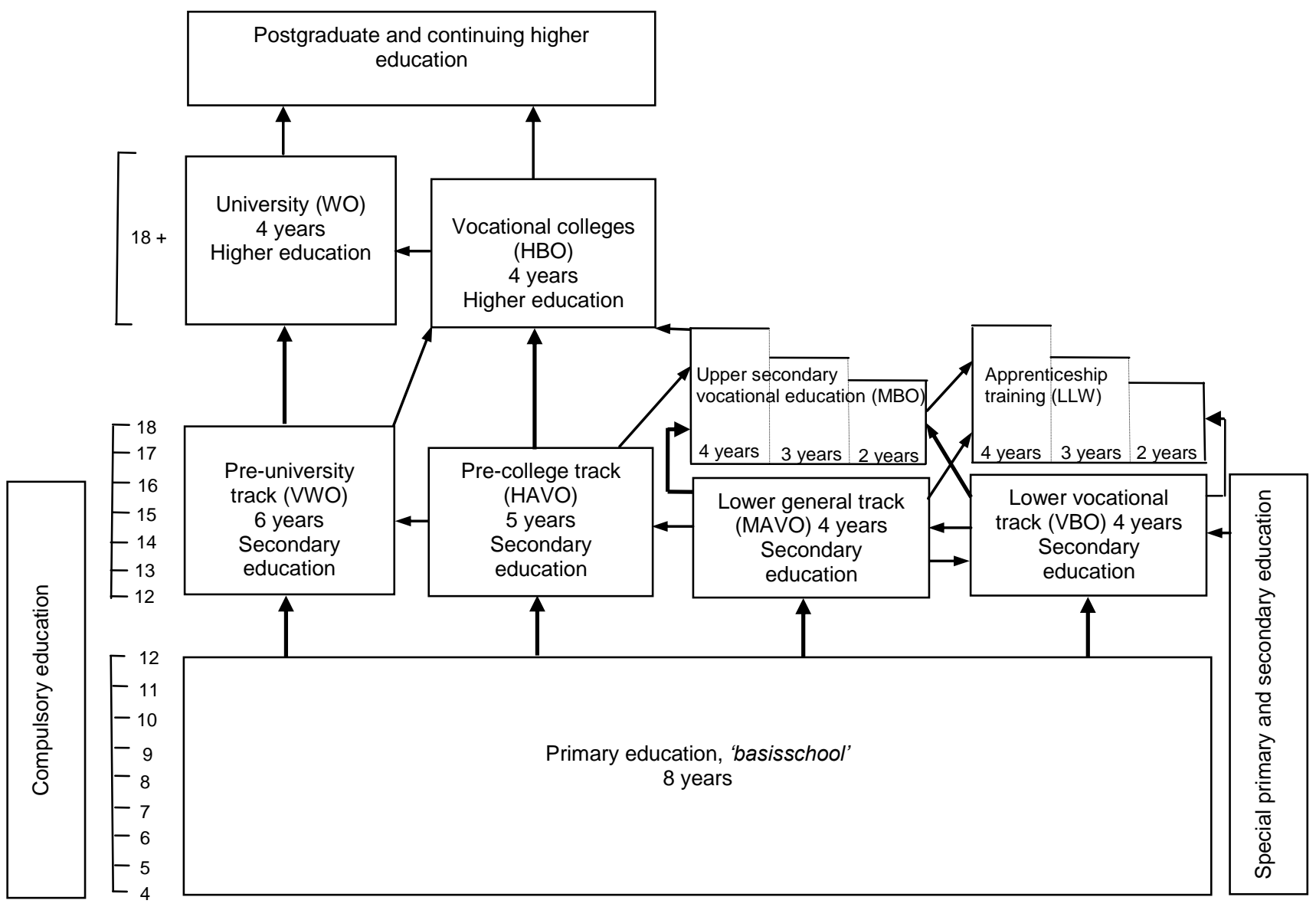


Table 1a: Estimated coefficients from log earning regressions, specified by educational level, males

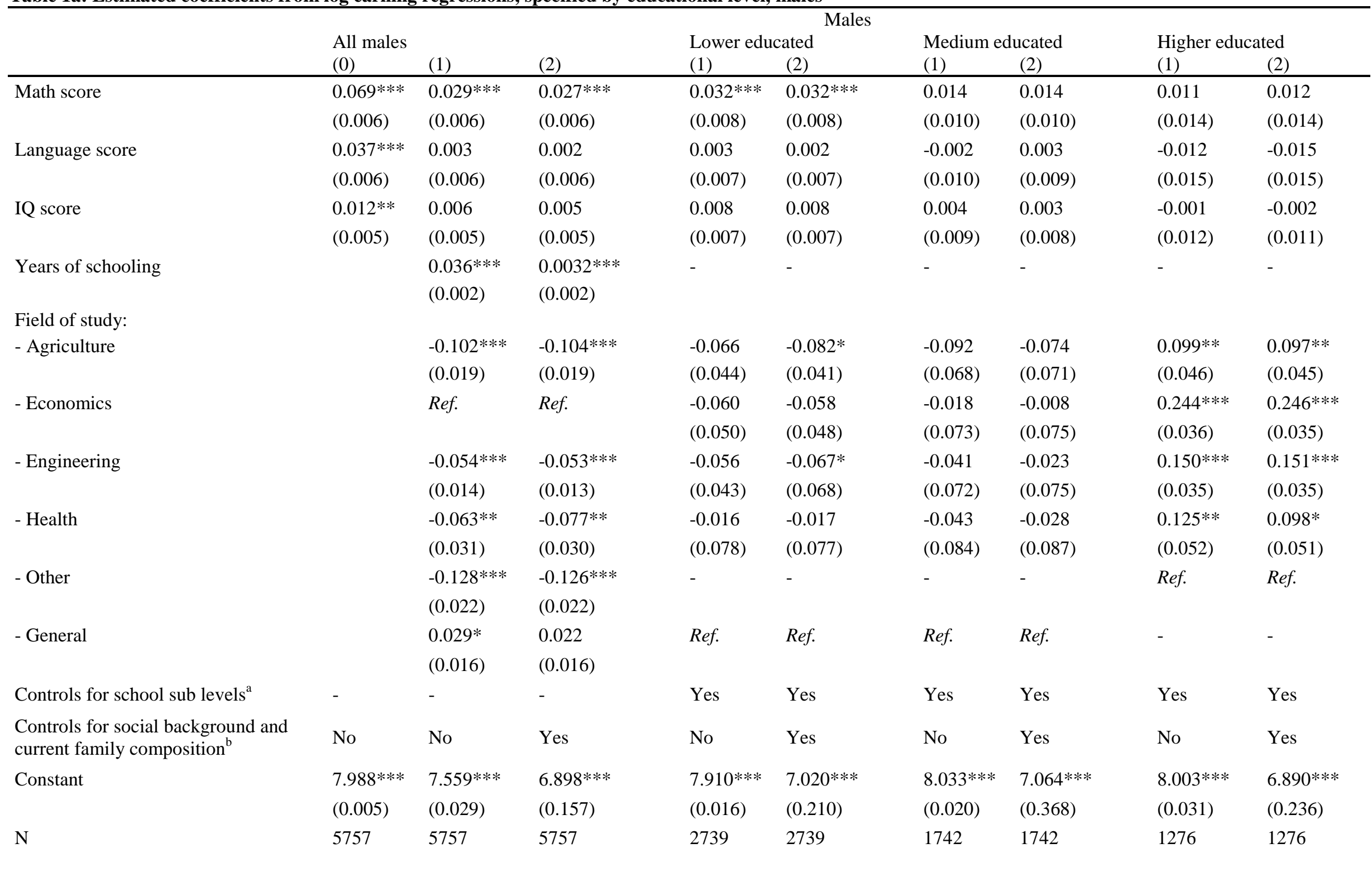



migration history). For some control variables we replaced the missing information by the population mean and included a dummy indicating the missing value, in order to avoid too many drop outs in the regression. These variables are: father's and mother's schooling, parental educational support at age 12, having a higher educated partner, partner's age and partner's age squared.

a) Within the low, medium and high education levels there are some minor differences in sublevels (e.g. as between BA and MA/MSc for higher educated students) for which we control.

b) Controls for social background include father's and mother's schooling the amount of parental educational support at age 12 and whether or not having one or more siblings,. Controls for family composition include having no, one or more children between the age of 4-12, having a child younger than 4 years old in the household, having a higher educated partner, whether or not the (existing) partner has any kind of income, partner's age and partner's age squared. 
Table 1b: Estimated coefficients from log earning regressions, specified by educational level, females

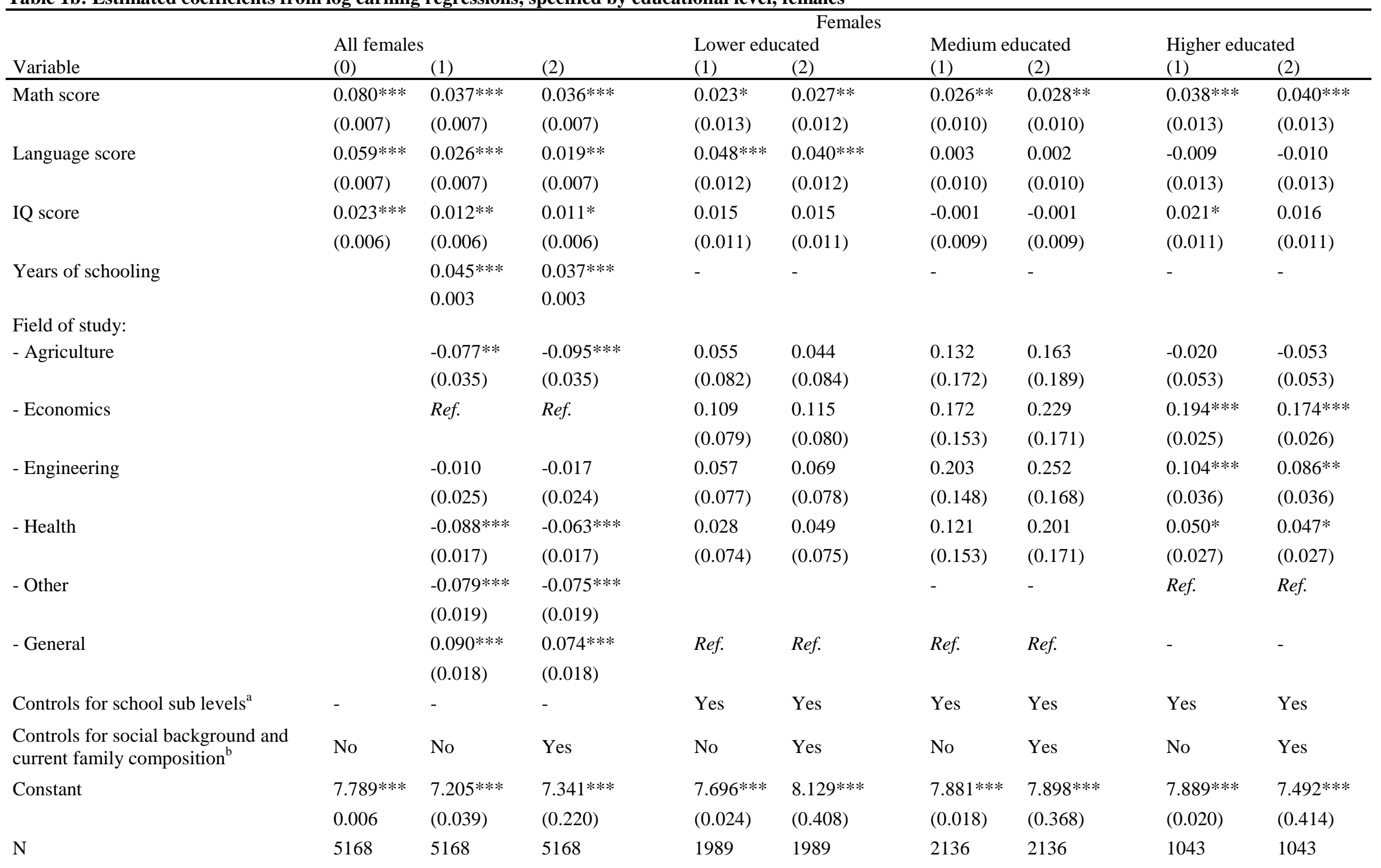


Note: $* * * \mathrm{p}<0.01 \quad * * \mathrm{p}<0.05 \quad * \mathrm{p}<0.10$; robust standard errors in parentheses; all estimates are corrected for selection into the labor market (exclusion criteria for females are: having a child younger than 4 years old in the household and whether or not the (existing) partner has any kind of income). For some control variables we replaced the missing information by the population mean and included a dummy indicating the missing value, in order to avoid too many drop outs in the regression. These variables are: father's and mother's schooling, parental educational support at age 12, having a higher educated partner, partner's age and partner's age squared.

a) Within the low, medium and high education levels there are some minor differences in sublevels (e.g. as between BA and MA/MSc for higher educated students) for which we control.

${ }^{b)}$ Controls for social background include father's and mother's schooling, the amount of parental educational support at age 12, having a migration history and whether or not having one or more siblings. Controls for family composition include having no, one or more children between the age of 4-12, having a higher educated partner (if existent), partner's age and partner's age squared.. 


\section{Figure 2a}

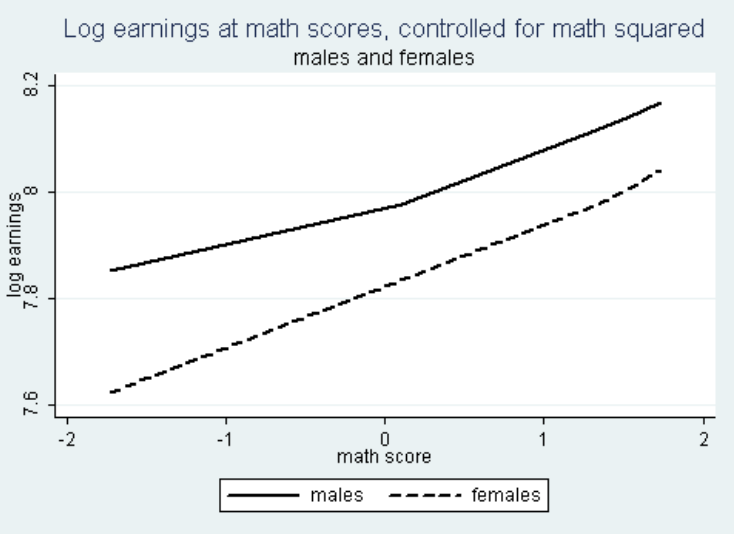

\section{Figure 2b}

Log earnings at language scores, controlled for language square

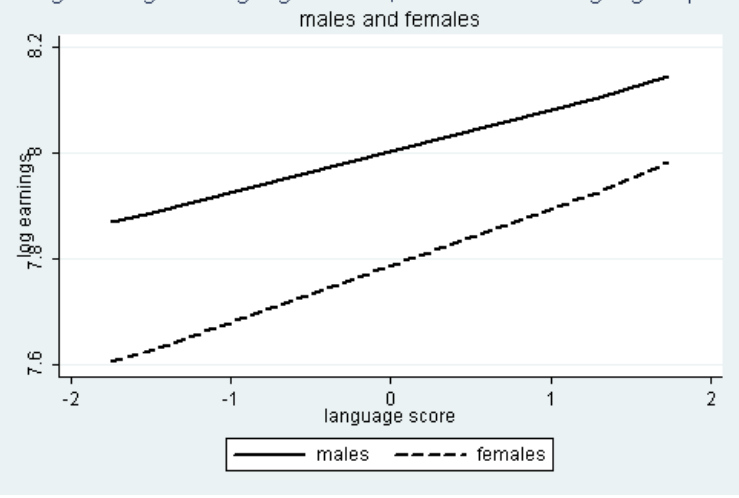

Figure 2c

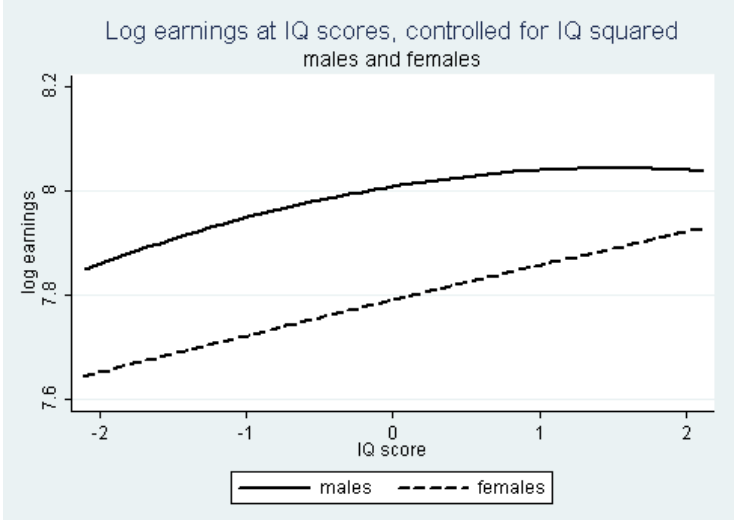


Table 2: OLS on years of schooling, separate for males and females

\begin{tabular}{|c|c|c|c|c|}
\hline & \multicolumn{2}{|l|}{ Males } & \multicolumn{2}{|l|}{ Females } \\
\hline & $(1)$ & $(2)$ & $(1)$ & $(2)$ \\
\hline \multirow[t]{2}{*}{ Math score } & $1.044 * * *$ & $0.961 * * *$ & $0.822 * * *$ & $0.716 * * *$ \\
\hline & $(0.049)$ & $(0.048)$ & $(0.047)$ & $(0.046)$ \\
\hline \multirow[t]{2}{*}{ Language score } & $0.824 * * *$ & $0.733 * * *$ & $0.641 * * *$ & $0.569 * * *$ \\
\hline & $(0.048)$ & $(0.047)$ & $(0.045)$ & $(0.044)$ \\
\hline \multirow[t]{2}{*}{ IQ score } & $0.215 * * *$ & $0.188 * * *$ & $0.289 * * *$ & $0.244 * * *$ \\
\hline & $(0.041)$ & $(0.041)$ & $(0.040)$ & $(0.039)$ \\
\hline \multirow[t]{2}{*}{ Schooling father } & & $0.371 * * *$ & & $0.324 * * *$ \\
\hline & & $(0.045)$ & & $(0.043)$ \\
\hline \multirow[t]{2}{*}{ Schooling mother } & & $0.245^{* * *}$ & & $0.225 * * *$ \\
\hline & & $(0.051)$ & & $(0.049)$ \\
\hline \multirow[t]{2}{*}{ Migration history } & & $-0.077 * * *$ & & $-0.696 * * *$ \\
\hline & & $(0.142)$ & & $(0.146)$ \\
\hline \multirow[t]{2}{*}{ Having siblings } & & 0.225 & & $0.373 * * *$ \\
\hline & & $(0.149)$ & & $(0.131)$ \\
\hline \multirow[t]{2}{*}{ Parents' educational support } & & 0.139 & & -0.054 \\
\hline & & $(0.141)$ & & $(0.136)$ \\
\hline $\mathrm{N}$ & 6425 & 6425 & 6912 & 6912 \\
\hline $\mathrm{R} 2$ & 0.237 & 0.267 & 0.175 & 0.211 \\
\hline
\end{tabular}

\section{Figure 3a}

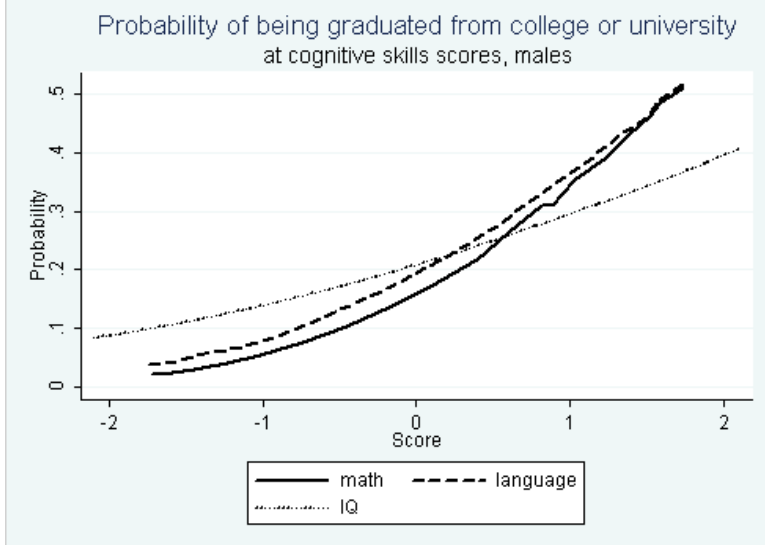

Figure 3b

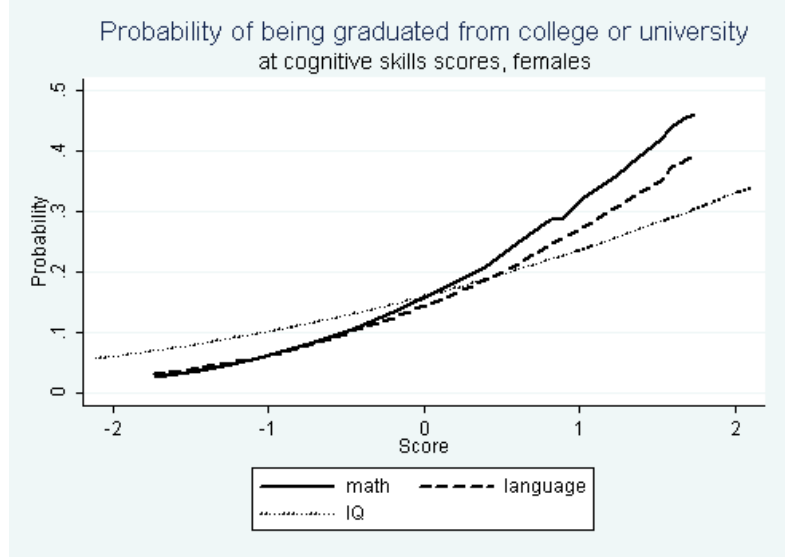


Table 3: Multinomial logit regression on field of study choice of males and females in higher education (predicted marginal effects)

\begin{tabular}{|c|c|c|c|c|c|}
\hline Males & agriculture & engineering & economics & health & other \\
\hline \multirow[t]{2}{*}{ Math score } & 0.004 & $0.063 * *$ & -0.017 & -0.009 & $-0.036^{* *}$ \\
\hline & $(0.009)$ & $(0.020)$ & $(0.018)$ & $(0.008)$ & $(0.012)$ \\
\hline \multirow[t]{2}{*}{ Language score } & -0.005 & $-0.048 * *$ & 0.018 & -0.005 & $0.041 * * *$ \\
\hline & $(0.007)$ & $(0.017)$ & $(0.017)$ & $(0.007)$ & $(0.012)$ \\
\hline \multirow[t]{2}{*}{ IQ score } & -0.002 & $0.060 * * *$ & -0.048 & -0.005 & -0.003 \\
\hline & $(0.006)$ & $(0.014)$ & $(0.014)$ & $(0.006)$ & $(0.010)$ \\
\hline $\mathrm{N}$ & 1370 & & & & \\
\hline Pseudo R2 & 0.016 & & & & \\
\hline Females & agriculture & engineering & economics & health & other \\
\hline \multirow[t]{2}{*}{ Math score } & $0.020 * * *$ & $0.046^{* * *}$ & 0.019 & $-0.068 * * *$ & -0.018 \\
\hline & $(0.006)$ & $(0.013)$ & $(0.018)$ & $(0.015)$ & $(0.019)$ \\
\hline \multirow[t]{2}{*}{ Language score } & $-0.012 * *$ & $-0.024 * *$ & $0.038 * *$ & -0.024 & 0.021 \\
\hline & $(0.005)$ & $(0.010)$ & $(0.018)$ & $(0.015)$ & $(0.020)$ \\
\hline \multirow[t]{2}{*}{ IQ score } & $0.010 * *$ & $0.042 * * *$ & -0.020 & -0.017 & -0.016 \\
\hline & $(0.005)$ & $(0.009)$ & $(0.015)$ & $(0.013)$ & $(0.016)$ \\
\hline $\mathrm{N}$ & 1187 & & & & \\
\hline Pseudo R2 & 0.032 & & & & \\
\hline
\end{tabular}


Figure 4a: Probability of graduating from engineering studies at math scores, higher educated males and females

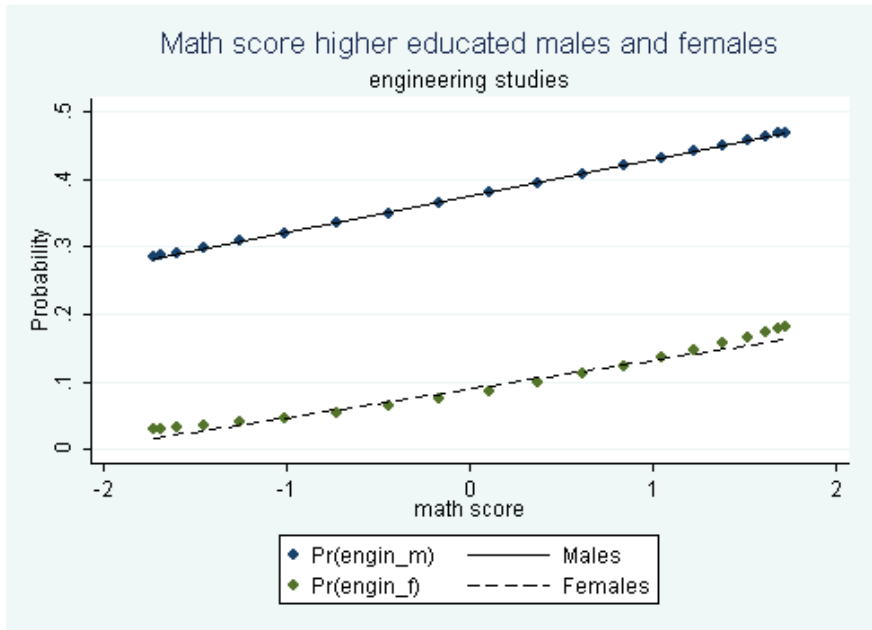

Figure 4b: Probability of graduating from economic studies at math scores, higher educated males and females

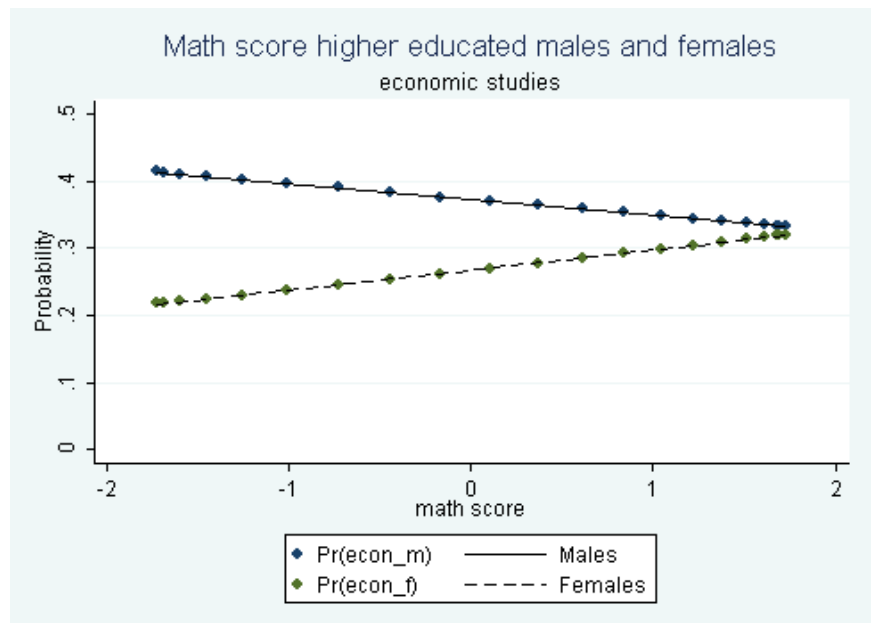




\begin{tabular}{lcccccc}
\hline & \multicolumn{2}{c}{ Males } & \multicolumn{2}{c}{ Females } & \\
& Mean & SD & Mean & SD & Min & Max \\
\hline Cognitive skills and education & & & & & & \\
Math score & 0.118 & 1.008 & -0.112 & 0.985 & -1.728 & 1.730 \\
Language score & -0.051 & 1.005 & 0.063 & 0.994 & -1.744 & 1.731 \\
IQ score & -0.038 & 1.005 & 0.047 & 0.998 & -2.111 & 2.111 \\
Years of schooling & 12.510 & 3.616 & 12.580 & 3.370 & 6 & 19 \\
Field of study (Dummies) & & & & & & \\
Agriculture & & & & & & 1 \\
Engineering & 0.056 & 0.231 & 0.024 & 0.154 & 0 & 1 \\
Health & 0.371 & 0.483 & 0.056 & 0.23 & 0 & 1 \\
Economics & 0.024 & 0.152 & 0.265 & 0.442 & 0 & 1 \\
Other & 0.174 & 0.379 & 0.176 & 0.381 & 0 & 1 \\
General & 0.058 & 0.234 & 0.091 & 0.287 & 0 & 1 \\
& 0.317 & 0.465 & 0.388 & 0.487 & 0 & 1 \\
Family background & & & & & & \\
Having a migration history & 0.092 & 0.289 & 0.087 & 0.282 & 0 & 1 \\
Having one or more siblings & 0.894 & 0.308 & 0.895 & 0.307 & 0 & 1 \\
Years of schooling mother & 9.434 & 3.47 & 9.308 & 3.505 & 6 & 19 \\
Years of schooling father & 10.334 & 4.076 & 10.254 & 4.073 & 6 & 19 \\
Educ. support by parents & 0.514 & 0.285 & 0.490 & 0.274 & 0 & 1 \\
Labor market characteristics & & & & & & \\
No job & 0.086 & 0.281 & 0.228 & 0.420 & 0 & 1 \\
Part time employed & 0.105 & 0.306 & 0.541 & 0.498 & 0 & 1 \\
Full time employed & 0.809 & 0.393 & 0.231 & 0.421 & 0 & 1 \\
Log monthly earnings & 7.993 & 0.369 & 7.796 & 0.432 & 3.332 & 10.188 \\
No child between 4-12 years & 0.717 & 0.451 & 0.521 & 0.500 & 0 & 1 \\
One child between 4-12 years & 0.174 & 0.379 & 0.277 & 0.448 & 0 & 1 \\
More children between 4-12 years & 0.109 & 0.311 & 0.202 & 0.401 & 0 & 1 \\
Child |< 4 years in household & 0.391 & 0.488 & 0.450 & 0.498 & 0 & 1 \\
Having a partner in 2005 & 0.725 & 0.446 & 0.799 & 0.401 & 0 & 1 \\
Having a higher educated partner & 0.265 & 0.442 & 0.222 & 0.415 & 0 & 1 \\
Partner has any kind of income & 0.628 & 0.483 & 0.780 & 0.414 & 0 & 1 \\
Age of the partner & 32.537 & 3.917 & 36.691 & 3.877 & 16 & 80 \\
\hline
\end{tabular}


Table A2: Summary statistics of selected variables, males and females by educational level ${ }^{14}$

\begin{tabular}{|c|c|c|c|c|c|c|c|c|c|}
\hline \multirow[b]{2}{*}{ Variable } & \multicolumn{2}{|c|}{ Lower education } & \multirow{2}{*}{$\begin{array}{c}\text { t-test } \\
p \text {-value }\end{array}$} & \multicolumn{2}{|c|}{ Medium education } & \multirow{2}{*}{$\begin{array}{c}\text { t-test } \\
\text { p-value }\end{array}$} & \multicolumn{2}{|c|}{ Higher education } & \multirow{2}{*}{$\begin{array}{c}t \text {-test } \\
p \text {-value }\end{array}$} \\
\hline & Males & Females & & Males & Females & & Males & Females & \\
\hline Log monthly earnings & 7.874 & 7.638 & 0.000 & 8.010 & 7.817 & 0.000 & 8.230 & 8.054 & 0.000 \\
\hline No job & 0.123 & 0.321 & 0.000 & 0.048 & 0.179 & 0.000 & 0.053 & 0.101 & 0.000 \\
\hline Part-time working & 0.095 & 0.493 & 0.000 & 0.095 & 0.586 & 0.000 & 0.142 & 0.564 & 0.000 \\
\hline Full-time working & 0.782 & 0.187 & 0.000 & 0.857 & 0.235 & 0.000 & 0.806 & 0.335 & 0.000 \\
\hline Math score & -0.332 & -0.516 & 0.000 & 0.369 & 0.038 & 0.000 & 0.820 & 0.583 & 0.000 \\
\hline Language score & -0.462 & -0.321 & 0.000 & 0.166 & 0.228 & 0.032 & 0.606 & 0.672 & 0.055 \\
\hline IQ score & -0.246 & -0.197 & 0.048 & 0.047 & 0.149 & 0.001 & 0.329 & 0.443 & 0.003 \\
\hline \multicolumn{10}{|l|}{ Field of study (Dummy): } \\
\hline - agriculture & 0.043 & 0.03 & 0.365 & 0.081 & 0.011 & 0.000 & 0.053 & 0.036 & 0.038 \\
\hline - economics & 0.048 & 0.082 & 0.000 & 0.259 & 0.235 & 0.249 & 0.353 & 0.285 & 0.000 \\
\hline - engineering & 0.397 & 0.050 & 0.000 & 0.290 & 0.038 & 0.000 & 0.42 & 0.115 & 0.000 \\
\hline - health & 0.006 & 0.215 & 0.000 & 0.035 & 0.348 & 0.000 & 0.049 & 0.206 & 0.000 \\
\hline - other & 0.063 & 0.068 & 0.073 & - & - & - & 0.126 & 0.358 & 0.000 \\
\hline - general & 0.442 & 0.555 & 0.000 & 0.335 & 0.368 & 0.000 & - & - & - \\
\hline One child between $4-12$ years & 0.200 & 0.322 & 0.000 & 0.167 & 0.262 & 0.000 & 0.124 & 0.195 & 0.000 \\
\hline More children between 4-12 years & 0.132 & 0.240 & 0.000 & 0.104 & 0.197 & 0.000 & 0.061 & 0.115 & 0.000 \\
\hline Having a child $\mid<4$ years & 0.360 & 0.362 & 0.950 & 0.414 & 0.509 & 0.000 & 0.433 & 0.544 & 0.000 \\
\hline Having a partner & 0.706 & 0.770 & 0.000 & 0.736 & 0.831 & 0.000 & 0.755 & 0.800 & 0.007 \\
\hline Having a higher educated partner & 0.112 & 0.096 & 0.075 & 0.277 & 0.215 & 0.000 & 0.585 & 0.550 & 0.115 \\
\hline Partner has any kind of income & 0.595 & 0.749 & 0.000 & 0.651 & 0.816 & 0.000 & 0.676 & 0.782 & 0.000 \\
\hline Age of partner & 32.66 & 36.991 & 0.000 & 32.371 & 36.506 & 0.000 & 32.646 & 36.384 & 0.000 \\
\hline
\end{tabular}

Note: Differences in math, language and IQ-scores between males of different educational levels and between females of different educational levels are all significant.

${ }^{14}$ The lower education level comprises ISCED 1 and 2; the medium education level comprises ISCED 3 and 4 and the higher education level ISCED 5 and 6. 
Table A3a: Multinomial logit regression on field of study choice of males (predicted marginal effects)

\begin{tabular}{|c|c|c|c|c|c|c|}
\hline All males & agriculture & engineering & economics & health & other & $\begin{array}{l}\text { general } \\
\text { secondary }\end{array}$ \\
\hline \multirow[t]{2}{*}{ Math score } & -0.004 & $-0.026 * * *$ & $0.030 * * *$ & 0.002 & $-0.008 * *$ & 0.007 \\
\hline & $(0.004)$ & $(0.008)$ & $(0.006)$ & $(0.002)$ & $(0.004)$ & $(0.007)$ \\
\hline \multirow[t]{2}{*}{ Language score } & $-0.012 * * *$ & $-0.061 * * *$ & $0.030 * * *$ & 0.001 & $0.012 * *$ & $0.030 * * *$ \\
\hline & $(0.003)$ & $(0.007)$ & $(0.006)$ & $(0.002)$ & $(0.004)$ & $(0.007)$ \\
\hline \multirow[t]{2}{*}{ IQ score } & -0.003 & $0.029 * * *$ & $-0.016^{* *}$ & -0.001 & 0.001 & $-0.010^{*}$ \\
\hline & $(0.003)$ & $(0.007)$ & $(0.005)$ & $(0.002)$ & $(0.003)$ & $(0.006)$ \\
\hline $\mathrm{N}$ & 6422 & & & & & \\
\hline Pseudo R2 & 0.014 & & & & & \\
\hline $\begin{array}{l}\text { Low educated } \\
\text { males }\end{array}$ & agriculture & engineering & economics & health & other & $\begin{array}{l}\text { general } \\
\text { secondary }\end{array}$ \\
\hline \multirow[t]{2}{*}{ Math score } & $-0.013 * *$ & $-0.068 * * *$ & -0.007 & -0.001 & $-0.009 *$ & $0.098 * * *$ \\
\hline & $(0.004)$ & $(0.011)$ & $(0.005)$ & $(0.001)$ & $(0.006)$ & $(0.011)$ \\
\hline \multirow[t]{2}{*}{ Language score } & $-0.009 *$ & $-0.085^{* * *}$ & $-0.011 * *$ & 0.002 & 0.001 & $0.102 * * *$ \\
\hline & $(0.005)$ & $(0.011)$ & $(0.005)$ & $(0.001)$ & $(0.006)$ & $(0.011)$ \\
\hline \multirow[t]{2}{*}{ IQ score } & -0.003 & 0.013 & 0.001 & $-0.002 *$ & 0.000 & -0.009 \\
\hline & $(0.004)$ & $(0.010)$ & $(0.004)$ & $(0.001)$ & $(0.005)$ & $(0.010)$ \\
\hline $\mathrm{N}$ & 3196 & & & & & \\
\hline Pseudo R2 & 0.039 & & & & & \\
\hline $\begin{array}{l}\text { Medium educated } \\
\text { males }\end{array}$ & agriculture & engineering & economics & health & other & $\begin{array}{l}\text { general } \\
\text { secondary }\end{array}$ \\
\hline \multirow[t]{2}{*}{ Math score } & $-0.019 * *$ & $-0.042 * *$ & $-0.046^{* *}$ & $-0.009 * *$ & - & $0.115 * * *$ \\
\hline & $(0.007)$ & $(0.014)$ & $(0.014)$ & $(0.004)$ & & $(0.016)$ \\
\hline \multirow[t]{2}{*}{ Language score } & $-0.033 * * *$ & $-0.073 * * *$ & -0.016 & $-0.011 * *$ & - & $0.133 * * *$ \\
\hline & $(0.006)$ & $(0.013)$ & $(0.013)$ & $(0.005)$ & & $(0.014)$ \\
\hline \multirow[t]{2}{*}{ IQ score } & -0.006 & $0.022 *$ & $0.051 * * *$ & 0.002 & - & $0.034 * *$ \\
\hline & $(0.006)$ & $(0.012)$ & $(0.012)$ & $(0.005)$ & & $(0.012)$ \\
\hline $\mathrm{N}$ & 1856 & & & & & \\
\hline Pseudo R2 & 0.067 & & & & & \\
\hline $\begin{array}{l}\text { High educated } \\
\text { males }\end{array}$ & agriculture & engineering & economics & health & other & $\begin{array}{l}\text { general } \\
\text { secondary }\end{array}$ \\
\hline \multirow[t]{2}{*}{ Math score } & 0.004 & $0.063 * *$ & -0.017 & -0.009 & $-0.036 * *$ & - \\
\hline & $(0.009)$ & $(0.020)$ & $(0.018)$ & $(0.008)$ & $(0.012)$ & \\
\hline \multirow[t]{2}{*}{ Language score } & -0.005 & $-0.048 * *$ & 0.018 & -0.005 & $0.041 * * *$ & - \\
\hline & $(0.007)$ & $(0.017)$ & $(0.017)$ & $(0.007)$ & $(0.012)$ & \\
\hline \multirow[t]{2}{*}{ IQ score } & -0.002 & $0.060 * * *$ & -0.048 & -0.005 & -0.003 & - \\
\hline & $(0.006)$ & $(0.014)$ & $(0.014)$ & $(0.006)$ & $(0.010)$ & \\
\hline $\mathrm{N}$ & 1370 & & & & & \\
\hline Pseudo R2 & 0.016 & & & & & \\
\hline
\end{tabular}


Table A3b: Multinomial logit regression on field of study choice of females (predicted marginal effects)

\begin{tabular}{|c|c|c|c|c|c|c|}
\hline All females & agriculture & engineering & economics & health & other & $\begin{array}{l}\text { general } \\
\text { secondary }\end{array}$ \\
\hline \multirow[t]{2}{*}{ Math score } & -0.003 & $0.011 * *$ & $0.023 * * *$ & $-0.069 * * *$ & $0.017 * * *$ & $0.021 * *$ \\
\hline & $(0.002)$ & $(0.003)$ & $(0.006)$ & $(0.007)$ & $(0.004)$ & $(0.008)$ \\
\hline \multirow[t]{2}{*}{ Language score } & -0.003 & $-0.014 * * *$ & $0.012 * *$ & $-0.048 * * *$ & 0.015 & $0.038 * * *$ \\
\hline & $(0.002)$ & $(0.003)$ & $(0.006)$ & $(0.006)$ & $(0.004)$ & $(0.007)$ \\
\hline \multirow[t]{2}{*}{ IQ score } & 0.002 & $0.008 * *$ & 0.001 & $-0.010 *$ & 0.005 & -0.005 \\
\hline & $(0.002)$ & $(0.003)$ & $(0.005)$ & $(0.006)$ & $(0.004)$ & $(0.007)$ \\
\hline $\mathrm{N}$ & 6911 & & & & & \\
\hline Pseudo R2 & 0.023 & & & & & \\
\hline $\begin{array}{l}\text { Low educated } \\
\text { females }\end{array}$ & agriculture & engineering & economics & health & other & $\begin{array}{l}\text { general } \\
\text { secondary }\end{array}$ \\
\hline \multirow[t]{2}{*}{ Math score } & $-0.014 * * *$ & $-0.016 * * *$ & -0.003 & $-0.064 * * *$ & -0.010 & $0.105 * * *$ \\
\hline & $(0.004)$ & $(0.005)$ & $(0.007)$ & $(0.011)$ & $(0.007)$ & $(0.013)$ \\
\hline \multirow[t]{2}{*}{ Language score } & 0.001 & $-0.024 * * *$ & $-0.002 * * *$ & $-0.056 * * *$ & -0.004 & $0.105^{* * *}$ \\
\hline & $(0.004)$ & $(0.004)$ & $(0.006)$ & $(0.010)$ & $(0.006)$ & $(0.012)$ \\
\hline \multirow[t]{2}{*}{ IQ score } & -0.002 & $-0.010 * *$ & -0.004 & -0.009 & 0.004 & $0.021 * *$ \\
\hline & $(0.003)$ & $(0.004)$ & $(0.005)$ & $(0.008)$ & $(0.005)$ & $(0.010)$ \\
\hline $\mathrm{N}$ & 3053 & & & & & \\
\hline Pseudo R2 & 0.048 & & & & & \\
\hline $\begin{array}{l}\text { Medium educated } \\
\text { females }\end{array}$ & agriculture & engineering & economics & health & other & $\begin{array}{l}\text { general } \\
\text { secondary }\end{array}$ \\
\hline \multirow[t]{2}{*}{ Math score } & -0.003 & 0.004 & -0.008 & $-0.139 * * *$ & - & $0.145 * * *$ \\
\hline & $(0.002)$ & $(0.004)$ & $(0.011)$ & $(0.012)$ & & $(0.013)$ \\
\hline \multirow[t]{2}{*}{ Language score } & -0.003 & -0.005 & -0.012 & $-0.114 * * *$ & - & $0.134 * * *$ \\
\hline & $(0.002)$ & $(0.004)$ & $(0.011)$ & $(0.012)$ & & $(0.013)$ \\
\hline \multirow[t]{2}{*}{ IQ score } & 0.002 & $0.010 * *$ & -0.002 & $-0.036 * * *$ & - & $0.026 * *$ \\
\hline & $(0.002)$ & $(0.004)$ & $(0.010)$ & $(0.011)$ & & $(0.011)$ \\
\hline $\mathrm{N}$ & 2671 & & & & & \\
\hline Pseudo R2 & 0.095 & & & & & \\
\hline $\begin{array}{l}\text { High educated } \\
\text { females }\end{array}$ & agriculture & engineering & economics & health & other & $\begin{array}{l}\text { general } \\
\text { secondary }\end{array}$ \\
\hline \multirow[t]{2}{*}{ Math score } & $0.020 * * *$ & $0.046 * * *$ & 0.019 & $-0.068 * * *$ & -0.018 & - \\
\hline & $(0.006)$ & $(0.013)$ & $(0.018)$ & $(0.015)$ & $(0.019)$ & \\
\hline \multirow[t]{2}{*}{ Language score } & $-0.012 * *$ & $-0.024 * *$ & $0.038 * *$ & -0.024 & 0.021 & - \\
\hline & $(0.005)$ & $(0.010)$ & $(0.018)$ & $(0.015)$ & $(0.020)$ & \\
\hline \multirow[t]{2}{*}{ IQ score } & $0.010 * *$ & $0.042 * * *$ & -0.020 & -0.017 & -0.016 & - \\
\hline & $(0.005)$ & (0.009) & $(0.015)$ & $(0.013)$ & $(0.016)$ & \\
\hline $\mathrm{N}$ & 1187 & & & & & \\
\hline Pseudo R2 & 0.032 & & & & & \\
\hline
\end{tabular}

